\title{
Military Organizational Culture in Protest Response
}

\author{
Nicholas J. Lotito \\ Yale University
}

February 2, 2020

\section{Introduction}

When mass protests overwhelm the capacity of the police, civilian authorities often rely on soldiers to restore order. Conventional wisdom holds that military protest response is a strategic decision motivated by factors like patronage or ethnicity. ${ }^{1}$ However, this logic fails to account for the realities of organizational decision making under crisis, in the moments of chaos produced by mass protests. In this article, I argue that the military relies on historical precedents to guide its institutional response to protests. While individual interests undoubtedly play into military officers' decisions, organizational culture and history are central factors guiding military behavior, whether at war or in peace, on the battlefield or in the streets. Soldiers rely on the military's organizational culture, a set of shared values, assumptions and beliefs, to guide their decision making, especially during crises. ${ }^{2}$ Military responses to protest, from violent repression to complete disengagement,

\footnotetext{
${ }^{1}$ Holger Albrecht and Dorothy Ohl, "Exit, Resistance, Loyalty: Military Behavior During Unrest in Authoritarian Regimes," Perspectives on Politics 14, no. 1 (March 2016): 38-52, doi:10.1017/S1537592715003217; Zoltan D. Barany, How Armies Respond to Revolutions and Why (Princeton, NJ: Princeton University Press, 2016); Hicham Bou Nassif, "Generals and Autocrats: How Coup-Proofing Predetermined the Military Elite's Behavior in the Arab Spring," Political Science Quarterly 130, no. 2 (June 2015): 245-75, doi:10.1002/polq.12324; Sharan Grewal, "Military Defection During Localized Protests: The Case of Tataouine," International Studies Quarterly 63, no. 2 (June 1, 2019): 259-69, doi:10.1093/isq/sqz003; Ore Koren, "Military Structure, Civil Disobedience, and Military Violence," Terrorism and Political Violence 26, no. 4 (September 1, 2014): 688-712, doi:10.1080/09546553.2012.760455; Terence Lee, Defect Or Defend: Military Responses to Popular Protests in Authoritarian Asia (JHU Press, 2015); Jesse Paul Lehrke, "A Cohesion Model to Assess Military Arbitration of Revolutions," Armed Forces \& Society 40, no. 1 (January 1, 2014): 146-67, doi:10.1177/0095327X12459851; Theodore McLauchlin, "Loyalty Strategies and Military Defection in Rebellion," Comparative Politics 42, no. 3 (April 1, 2010): 333-50; Julien Morency-Laflamme, "A Question of Trust: Military Defection During Regime Crises in Benin and Togo," Democratization 25, no. 3 (2018): 464-80, doi:10.1080/13510347.2017.1375474; Sharon Erickson Nepstad, "Mutiny and Nonviolence in the Arab Spring Exploring Military Defections and Loyalty in Egypt, Bahrain, and Syria," Journal of Peace Research 50, no. 3 (May 1, 2013): 337-49, doi:10.1177/0022343313476529; David Pion-Berlin, Diego Esparza, and Kevin Grisham, "Staying Quartered: Civilian Uprisings and Military Disobedience in the Twenty-First Century," Comparative Political Studies 47, no. 2 (February 1, 2014): 230-59, doi:10.1177/0010414012450566.

${ }^{2}$ Following Elizabeth Kier, "I define organizational culture as the set of basic assumptions and values that shape shared understandings, and the forms or practices whereby these meanings are expressed, affirmed, and communicated to the members of an organization." -Elizabeth Kier, "Culture and Military Doctrine: France Between the Wars," International Security 19, no. 4 (1995): 65-93, doi:10.2307/2539120, 69-70.
} 
are driven by soldiers' shared understandings about their proper roles and missions, duties and responsibilities, and relationship to both ruler and ruled.

This article identifies three principal sources of organizational culture in postcolonial armies: the military's institutional origins, role in national independence, and relationship to the ruling party. These factors have lasting effects, I argue, because organizational culture tends to be stable, changing only gradually over the decades. Next, I apply the theory to the Arab Spring protests of 20102011 and demonstrate the causal mechanism in the Tunisian case. The role of the military in producing Tunisia's largely nonviolent, prodemocratic regime transition has been widely lauded by scholars and policymakers alike. However, the conventional explanation for this outcome namely, the lack of regime patronage toward military officers - does not fit the observed pattern of military response. Rather than move to oust Ben Ali, the military never disobeyed his orders, senior officers remained personally loyal to the president during the unrest. Instead, the army's culture of restraint led soldiers to intervene to defend state institutions, but to avoid arbitrating or escalating the dispute. Archival materials and original interviews with retired Tunisian military officers, government ministers, and security experts offer strong evidence of a cultural mechanism guiding the army's response. ${ }^{3}$ I conclude with directions for future research on the role of organizational culture in military behavior.

\section{Military Protest Response}

When called to the streets during moments of overwhelming popular mobilization, why do soldiers sometimes respond with violence? Most existing research frames the question in terms of defection and points to various factors believed to influence the military's loyalty to the political regime. In this view, the critical question for military officers is whether to "defect or defend."4 Loyalty is an appealing explanation because it fits cleanly into a rational choice, political economy framework. Whether loyalty stems from officers' values (professionalism), material interests (patronage) or identity ties (ethnicity), it is assumed that soldiers will refrain from challenging the political regime, and will even fight to defend it, as long as they remain faithful to its leader. Each of these variables - professionalism, patronage, and ethnicity - contributes to the military's political interests. Still, the strategic loyalty framework is inadequate to explain how these factors shape the behavior of the military organization as a whole.

Military professionalism has long been the master variable of civil-military relations theory. ${ }^{5}$ In the classical view, military professionalism encourages depoliticization and submission to civilian control, through ideological mechanisms. ${ }^{6}$ Although a broad literature exists lauding the merits of professionalization, the widespread assumption in this writing that military professionalism in-

\footnotetext{
${ }^{3}$ See methodological appendix for details of research design, case selection, and qualitative data sources.

${ }^{4}$ Lee, Defect Or Defend.

${ }^{5}$ Peter D. Feaver, "The Civil-Military Problematique: Huntington, Janowitz, and the Question of Civilian Control," Armed Forces \& Society 23, no. 2 (January 1996): 149-78, doi:10.1177/0095327X9602300203.

${ }^{6}$ Samuel P. Huntington, The Soldier and the State: The Theory and Politics of Civil-Military Relations (Cambridge, MA: Harvard University Press, 1957); Morris Janowitz, The Professional Soldier (Free Press, 1964); Peter D. Feaver, "Civil-Military Relations," Annual Review of Political Science 2, no. 1 (1999): 211-41, doi:10.1146/annurev.polisci.2.1.211; Zoltan Barany, The Soldier and the Changing State: Building Democratic Armies in Africa, Asia, Europe, and the Americas (Princeton, NJ: Princeton University Press, 2012).
} 
herently promotes democratic values is misguided. Because civilian control is considered a "sine qua non for democratic consolidation," "7 many assume without theoretical justification that increasing professionalism will cause democratization. In reality, military professionalism has also often sustained imperialism and authoritarianism. ${ }^{8}$ In less democratic contexts, the relationship between civilian authority and popular legitimacy - critical to a classical conception of military professionalism - breaks down. Rather than assure apoliticism, military professionalism "in fact often thrusts the military into collision with the civil authorities." 9 Professionalism encourages political interventionism when the military or national interest, as perceived and defined by the officer corps, is threatened. ${ }^{10}$ Mirroring the ambiguities of the theoretical literature, empirical studies of the Arab Spring have made inconsistent claims regarding the role of professionalism. ${ }^{11}$

At the same time, research on military professionalism has picked up on

A second school of thought holds that military loyalty can be effectively bought. This is the core assumption behind much of the game theoretic literature on civil-military relations. In a principalagent framework, the regime, ever fearful of a coup d'état, tries to buy the loyalty of the armed forces by satisfying their material interests. Military interventionism results when the regime fails to adequately compensate the military, economically or politically, for its continued support. ${ }^{12}$ Fo-

\footnotetext{
${ }^{7}$ Aurel Croissant et al., "Beyond the Fallacy of Coup-Ism: Conceptualizing Civilian Control of the Military in Emerging Democracies," Democratization 17, no. 5 (October 1, 2010): 960, doi:10.1080/13510347.2010.501180.

${ }^{8}$ Alfred C. Stepan, Rethinking Military Politics: Brazil and the Southern Cone (Princeton, NJ: Princeton University Press, 1988); Robin Luckham, "The Military, Militarization and Democratization in Africa: A Survey of Literature and Issues," African Studies Review 37, no. 2 (September 1, 1994): 13-75, doi:10.2307/524766; Mehran Kamrava, "Military Professionalization and Civil-Military Relations in the Middle East," Political Science Quarterly 115, no. 1 (March 1, 2000): 67-92, doi:10.2307/2658034.

${ }^{9}$ Samuel E. Finer, The Man on Horseback: The Role of the Military in Politics (New York: Praeger, 1962), 25.

${ }^{10}$ Alfred C. Stepan, Authoritarian Brazil: Origins, Policies, and Future (New Haven: Yale University Press, 1973), chap. 2; Kamrava, "Military Professionalization and Civil-Military Relations in the Middle East"; Tobias Böhmelt, Abel Escribà-Folch, and Ulrich Pilster, "Pitfalls of Professionalism? Military Academies and Coup Risk," Journal of Conflict Resolution, August 13, 2018, 0022002718789744 , doi:10.1177/0022002718789744.

${ }^{11}$ Derek Lutterbeck, "Arab Uprisings, Armed Forces, and Civil-Military Relations," Armed Forces \& Society 39, no. 1 (January 1, 2013): 28-52, doi:10.1177/0095327X12442768; Eva Bellin, "Reconsidering the Robustness of Authoritarianism in the Middle East: Lessons from the Arab Spring," Comparative Politics 44, no. 2 (January 1, 2012): 127-49, doi:10.5129/001041512798838021; F. Gregory Gause, "Why Middle East Studies Missed the Arab Spring: The Myth of Authoritarian Stability," Foreign Affairs, July 2011, https://www.foreignaffairs.com/articles/northafrica/2011-07-01/why-middle-east-studies-missed-arab-spring; Zoltan Barany, "The Role of the Military," Journal of Democracy 22, no. 4 (2011): 24-35, doi:10.1353/jod.2011.0069.

${ }^{12}$ Leonid Hurwicz, "But Who Will Guard the Guardians?" The American Economic Review 98, no. 3 (2008): 577-85; Timothy Besley and James A. Robinson, "Quis Custodiet Ipsos Custodes? Civilian Control Over the Military," Journal of the European Economic Association 8, no. 2-3 (April 5, 2010): 655-63, doi:10.1111/j.1542-4774.2010.tb00535.x; Milan W. Svolik, "Contracting on Violence: The Moral Hazard in Authoritarian Repression and Military Intervention in Politics," Journal of Conflict Resolution 57, no. 5 (2013): 765-94, doi:10.1177/0022002712449327; Brett Allen Casper and Scott A. Tyson, "Popular Protest and Elite Coordination in a Coup d'état," The Journal of Politics 76, no. 2 (April 2014): 548-64, doi:10.1017/S0022381613001485; Gabriel Leon, "Loyalty for Sale? Military Spending and Coups d'etat," Public Choice 159, no. 3-4 (June 1, 2014): 36383, doi:10.1007/s11127-013-0124-4; R. Blake McMahon and Branislav L. Slantchev, "The Guardianship Dilemma: Regime Security Through and from the Armed Forces," American Political Science Review 109, no. 2 (May 2015): 297-313, doi:10.1017/S0003055415000131; J. Atsu Amegashie, "Regime Spoiler or Regime Pawn: The Military and Distributional Conflict in Non-Democracies," Journal of Comparative Economics 43, no. 2 (May 2015): 491-502, doi:10.1016/j.jce.2014.04.004.
} 
cused on coups d'état, these models treat both coup attempts and military defection during mass protests as examples of interventionism. ${ }^{13}$ I argue that the focus on loyalty, especially from an economic perspective, is misplaced. The loyalty paradigm presumes that the armies most likely to carry out a coup d'état are also the most likely to defect from the regime during a popular uprising. In fact, armies with no history of coup-plotting have nevertheless "defected" from regimes facing popular revolts, and vice versa.

Finally, studies of ethnically divided societies often focus on the ethnic composition of the armed forces, relative to the political regime and to society at large, as a primary causal variable. The literature finds that armies are less prone to violent repression when their own ethnic or ideological composition mirrors that of society at large. ${ }^{14}$ Conversely, military responses are more violent when "ethnic stacking" fills the upper echelons of the military hierarchy with "co-ethnics" of the embattled leader. ${ }^{15}$ Ethnicity also shapes protest responses indirectly, through its effect military cohesion. ${ }^{16}$ These studies leave little doubt that ethnic bias in the military can have substantial effects on protest response; however, the effect results from the politicization of ethnicity, not ethnic composition per se. It is therefore necessary to explore why and how ethnic identity becomes salient within the military in the first place.

\section{Military Organizational Culture}

As demonstrated above, the existing literature generally assumes that senior officers' strategic interests are the immediate cause of military responses. Instead, I begin with a different question: When confronting mass protests, how does the military make decisions? Like any organization, armies respond to events based on their existing practices and knowledge. Organizational culture originates in the circumstances of the institution's founding. Thereafter, historical experience informs processes of organizational learning, which prepare the ground for future decisions.

My view of organizational culture draws on the work of sociologist Ann Swidler, who argues that culture provides a particular and limited "way of organizing action." 17 In this tradition, Elizabeth Kier argues that the military's "culture has independent explanatory power" over its behavior. ${ }^{18}$ Military culture is evidenced by values and attitudes regarding both "the military's relationship

\footnotetext{
${ }^{13}$ Casper and Tyson, "Popular Protest and Elite Coordination in a Coup d'état."

${ }^{14}$ Cynthia H. Enloe, "Police and Military in the Resolution of Ethnic Conflict," The ANNALS of the American Academy of Political and Social Science 433, no. 1 (September 1, 1977): 137-49, doi:10.1177/000271627743300113; McLauchlin, "Loyalty Strategies and Military Defection in Rebellion"; Michael Makara, "Coup-Proofing, Military Defection, and the Arab Spring," Democracy and Security 9, no. 4 (September 1, 2013): 334-59, doi:10.1080/17419166.2013.802983; Lehrke, "A Cohesion Model to Assess Military Arbitration of Revolutions"; Hicham Bou Nassif, "'Second-Class': The Grievances of Sunni Officers in the Syrian Armed Forces," Journal of Strategic Studies 38, no. 5 (July 29, 2015): 626-49, doi:10.1080/01402390.2015.1053604; Julien Morency-Laflamme and Theodore McLauchlin, "The Efficacy of Ethnic Stacking: Military Defection During Uprisings in Africa," Journal of Global Security Studies, 2019, doi:10.1093/jogss/ogz015.

${ }^{15}$ Lutterbeck, "Arab Uprisings, Armed Forces, and Civil-Military Relations."

${ }^{16}$ Albrecht and Ohl, "Exit, Resistance, Loyalty."

${ }^{17}$ Ann Swidler, "Culture in Action: Symbols and Strategies," American Sociological Review 51, no. 2 (1986): 274 78.

${ }^{18}$ Kier, "Culture and Military Doctrine," 69.
} 
with its external environment" and "the internal workings of the organization."19 Organizational culture determines which courses of action soldiers perceive as possible, particularly in a crisis.

Existing scholarship recognizes the role of organizational culture in military behavior, including combat performance ${ }^{20}$ and coups d'état. ${ }^{21}$ This research recognizes that the military's institutional preferences are not determined by structural conditions alone. Instead, Kier observes, "Preferences are endogenous; they must be understood within their cultural context." ${ }^{22}$ This approach recognizes the role of factors like culture and routine in shaping behavior, rather than assuming a fully rational, strategic decision making process.

From the cultural perspective, military responses are guided by organizational factors, which may not be primarily strategic and interest-based. Organization theory has long recognized that bottom-up processes, beginning with the lowest "rungs" of the organizational ladder, can determine organization-level outcomes. ${ }^{23}$ Decision making under crisis, as during a war or mass protest, is especially dependent on organizational beliefs and routines established prior to the crisis. Military units deployed during mass protests rely on cultural factors like experience and routine when carrying out their orders. For example, the unit commander's decision making may draw on his personal command experience, his training and the rules of engagement (if any) for order maintenance operations, and his beliefs about the threat that protesters pose to national security. In this way, the military bureaucracy's lowest rungs, the soldiers on the ground, create organization-level outcomes.

\subsection{Military Protest Response: The Role of Organizational Culture}

While research has recognized the influence of organizational culture in other decision making contexts, it has failed to apply this logic to military protest response. During mass protests, when the potential collapse of a political regime thrusts soldiers into a central decision making role, these organizational factors constrain the military's pursuit of its strategic interests. When soldiers respond to popular uprisings, the military's repertoire of action comes into confrontation with protesters' "repertoire of contention" in streets and public squares across the country. ${ }^{24}$ The interaction between the dynamic processes of contestation on both sides can generate outcomes far outside the control of military planners in the Ministry of Defense or presidential palace. While political con-

\footnotetext{
${ }^{19}$ Ibid., 70.

${ }^{20}$ Barry R Posen, The Sources of Military Doctrine: Britain, France, and Germany Between the World Wars (Ithaca, NY: Cornell University Press, 1984); Jack Snyder, The Ideology of the Offensive: Military Decision Making and the Disasters of 1914 (Ithaca, NY: Cornell University Press, 1984); Kimberly Marten Zisk, Engaging the Enemy: Organization Theory and Soviet Military Innovation, 1955-1991 (Princeton, NJ: Princeton University Press, 1993); Elizabeth Kier, Imagining War: French and British Military Doctrine Between the Wars (Princeton, NJ: Princeton University Press, 1997); Austin Long, The Soul of Armies: Counterinsurgency Doctrine and Military Culture in the US and UK, Cornell Studies in Security Affairs (Ithaca, NY: Cornell University Press, 2016).

${ }^{21}$ Alfred C. Stepan, The Military in Politics: Changing Patterns in Brazil (Princeton, NJ: Princeton University Press, 1971); Kenneth M. Pollack, Arabs at War: Military Effectiveness, 1948-1991, Studies in War, Society, and the Military (Lincoln, NE: University of Nebraska Press, 2002); Barany, The Soldier and the Changing State; Caitlin Talmadge, "The Puzzle of Personalist Performance: Iraqi Battlefield Effectiveness in the Iran-Iraq War," Security Studies 22, no. 2 (2013): 180-221, doi:10.1080/09636412.2013.786911.

${ }^{22}$ Kier, "Culture and Military Doctrine," 67.

${ }^{23}$ James Q Wilson, Bureaucracy: What Government Agencies Do and Why They Do It (Basic Books, 1989).

${ }^{24}$ Charles Tilly, From Mobilization to Revolution (New York: Random House, 1978), chap. 5.
} 
siderations may also guide military behavior, relatively few senior officers are in a position to consider political strategy in the midst of the security crisis presented by ongoing protests. Instead, soldiers' initial actions draw on a pre-existing understanding of the military mission and role in internal security, as well as formal and informal guidelines for carrying out that mission.

In this context, military culture does not connote a universal orientation or value-system, but rather the unique culture of each army, rooted in its own history. Since the late nineteenth century, driven by the exigencies of modern warfare, states have adopted similar modes of military organization. ${ }^{25}$ While military cultures vary widely, they are shaped by similar factors, including the army's institutional origins, foreign influences, and historical experience. Although culture is specific to each organization, we can identify similar factors shaping the development of culture across all military organizations.

Organization theorists describe organizational learning as routine-based, history-dependent, and target-oriented. Routines are the cornerstone of organizational behavior, providing individuals with a playbook of appropriate actions for a wide range of scenarios. They are also a conduit for organizational memory, developed and modified through the retrospective evaluation of past successes and failures, and then transmitted to new generations within the organization. ${ }^{26}$ When strategic thinking does change beliefs and modify routines, it tends to be based on binary evaluations of past performances as successes or failures, rather than expectations for the future. ${ }^{27}$ However, in making these judgments, individuals suffer from common perceptual biases (e.g., availability bias and disregard for sample size), which lead organizations to learn lessons imperfectly. ${ }^{28}$

Organization theory yields several insights for military behavior. The historical context of a military's development is a critical factor in its future actions. Existing theories based only on the military's interests at the moment of crisis fail to account for history-dependent, routine-based behavior. Instead, the military organization's collective interpretations of past interventions generate and update routines to guide future responses. These routines persist in the lessons taught to new recruits through their education and training. When responding to an uprising, military officers are more likely to follow these established routines than to spontaneously diverge from the existing doctrine. When officers evaluate an engagement or intervention, they will tend to judge the mission sharply as a success or failure. Therefore, the lessons learned from an intervention depend primarily on whether the overall outcome is judged as good or bad, not a granular estimation of points of success and failure. In turn, definitions of success and failure depend on how the military understands its primary roles and missions (i.e., the organization's target). In this way, the military's shared interpretations of the past are a part of the evolving cultural context that informs military decision making.

\footnotetext{
${ }^{25}$ Joao Resende-Santos, Neorealism, States, and the Modern Mass Army (Cambridge University Press, 2007); Stephen D. Biddle, Military Power: Explaining Victory and Defeat in Modern Battle (Princeton, NJ: Princeton University Press, 2004).

${ }^{26}$ Barbara Levitt and James G. March, “Organizational Learning," Annual Review of Sociology 14 (1988): 327.

${ }^{27}$ This is because, when evaluating past experience, individuals in organizations draw sharper distinctions "between success and failure than among gradations of either" (ibid., 320-23).

${ }^{28}$ Amos Tversky and Daniel Kahneman, "Rational Choice and the Framing of Decisions," The Journal of Business 59, no. 4 (1986), doi:10.2307/2352759.
} 


\subsection{Military Cultures in the Developing World}

This section discusses the general pattern of military organizational development in the developing world, focusing on former British and French colonies in the Middle East and North Africa. I identify three primary components of this historical evolution. The formative period of military development in the region began with the foundation of modern military institutions, usually during the colonial era, and extends through the first decades of independence. A first source of culture is the army's colonial precursor. As the European colonies of the Middle East and North Africa gained their independence, they established national armies which drew heavily from their colonial precursors. The new armies inherited much of their culture, and often their officers as well, from the colonial-era military, and followed many of the same patterns of behavior after independence. ${ }^{29}$

The national independence movement provides a second source of military culture. The army's role in fighting for national liberation strongly shapes its understanding of its role and purpose. For example, Algeria's People's National Army is a direct descendant of the National Liberation Army which fought the war of independence. As a result, Algerian military culture draws heavily on the army's self-image as guardian of the nation. Moreover, the modern states of Algeria, Egypt, and Turkey were each founded by military officers: Houari Boumédiène, the Free Officers (including Gamal Abdel Nasser and Anwar Sadat), and Mustafa Kemal Atatürk, respectively. This militaryled national liberation established the guardianship of the military over the nation from the first days of independence, creating a powerful nationalist narrative to support this unique military role. ${ }^{30}$ To the contrary, Tunisia's independence was won through diplomacy, not war, so the newly constituted Tunisian National Army could make no nationalist claims to supragovernmental legitimacy.

Finally, where the military has a close relationship with the ruling party, political considerations will play a greater role in the military's approach to domestic security. Where the military is more autonomous, military beliefs and practices are more insulated from political control. In most Arab countries, the minister of defense is a military officer and there is little civilian oversight of the defense establishment. Officers possess technical expertise which civilian commanders do not have, and this informational advantage allows them greater control over the content of doctrine. ${ }^{3132}$ Second, culture can be difficult to change because it consists in and of the combined beliefs and practices of an entire organization. As a result, changing military culture from the outside is not as simple as signing an order. Nevertheless, the regime's efforts to shape military culture do have a tangible effect.

In postcolonial settings, military cultures reflect the historical experience of colonialism and the unique challenges of state-building. Modern armies were founded across much of the developing world in the colonial and early independence eras, from the late nineteenth to mid-twentieth century. Initially, military cultures were shaped by the design of colonial institutions, as well as the army's

\footnotetext{
${ }^{29}$ Elizabeth R. Nugent, "The Political Psychology of Repression and Polarization in Authoritarian Regimes" (PhD diss., Princeton University, 2017), chap. 3.

${ }^{30}$ Steven A Cook, Ruling but Not Governing: The Military and Political Development in Egypt, Algeria, and Turkey (Baltimore: Johns Hopkins University Press, 2007), 28-31.

${ }^{31}$ Peter Feaver, Armed Servants: Agency, Oversight, and Civil-Military Relations (Harvard University Press, 2005), $69-70$.

${ }^{32}$ The exception is often the authoritarian leader himself, who usually has a military background. However, his background does not guarantee the military institution will share all relevant information.
} 
relationship to the national independence movement and ruling political party. Over time, military cultures evolved, as officers gained experience in military interventions and trained new generations of soldiers. Within a few decades of independence, post-colonial regimes tended to stabilize, and the military became institutionalized within the new political order. As state institutions stabilized, the military's cultural values became internalized, routinized, and formalized. Occasionally, mass protests put the military's existing culture to the test, and these experiences caused soldiers to develop new ways of thinking about mass protests and their own role in regime security. When popular challenges to the post-colonial, authoritarian order later erupted - as they did during the "Third Wave" of democratization or the Arab Spring - armies' established organizational cultures guided their divergent responses to the uprisings.

\section{Military Culture in the Arab Spring}

A wave of protest, popularly known as the "Arab Spring" (Arabic: al-rabī' al- 'arabī), began in Tunisia in December 2010. Protests continued to escalate until President Zine el-Abidine ben Ali fled the country on January 14. Due to the strength of Middle Eastern regimes' coercive apparatuses, few previous protests had achieved high levels of mass mobilization. ${ }^{33}$ Precursors to this mobilization can be found in many smaller, often regional-based protest movements, as well as national strikes, riots, and events often classified, somewhat dismissively, as "social unrest." 34 The Arab Spring filled public squares with many first-time protesters, alongside experienced social, religious, and political activists and organizations. ${ }^{35}$ Fueled by international media coverage, notably on the Qatar-based Al-Jazeera satellite television network, anti-regime protests spread to nearly every country in the region, although only some protests escalated to revolutionary proportions, notably in Tunisia, Egypt, Libya, Syria, Bahrain, and Yemen.

As protests continued through the spring of 2011, it became increasingly evident that the response of each country's military to the protests would have a defining effect on the political success or failure of the revolutionary moment. ${ }^{36}$ Where national armies did not engage in repressing the protests (Egypt and Tunisia), old political leaders were swept from power. But where national armies brought to bear their full military might against civilians (Bahrain and Syria), existing regimes remained in power. Even where the military split apart (Libya and Yemen), and mutinous troops

\footnotetext{
${ }^{33}$ The Arab Spring was unprecedented within the region in terms of spontaneous, cross-class, nationwide anti-regime protests; in the previous three decades, only the Iranian Revolution of 1979 and Algeria's Black October riots of 1988 saw comparable mobilization. Eva Bellin, "The Robustness of Authoritarianism in the Middle East: Exceptionalism in Comparative Perspective," Comparative Politics 36, no. 2 (January 2004): 139-57, doi:10.2307/4150140.

${ }^{34}$ Didier Le Saout and Marguerite Rollinde, eds., Emeutes et mouvements sociaux au Maghreb : perspective comparée (Saint-Denis, France: Institut Maghreb-Europe, 1999); Laryssa Chomiak and John P. Entelis, "The Making of North Africa's Intifadas," Middle East Report 41, no. 259 (2011), http://www.merip.org/mer/mer259/making-northafricas-intifadas; Lina H. Khatib and Ellen Lust, eds., Taking to the Streets: The Transformation of Arab Activism (Baltimore: The Johns Hopkins University Press, 2014).

${ }^{35}$ Lisa Anderson, "Demystifying the Arab Spring," Foreign Affairs 90, no. 3 (June 2011): 2-7; Ricardo Larémont, ed., Revolution, Revolt and Reform in North Africa: The Arab Spring and Beyond (New York: Routledge, 2013); Fawaz A. Gerges, The New Middle East: Protest and Revolution in the Arab World (New York: Cambridge University Press, 2014).

${ }^{36}$ Bellin, "Reconsidering"; Lutterbeck, "Arab Uprisings, Armed Forces, and Civil-Military Relations"; Jason Brownlee, Tarek E. Masoud, and Andrew Reynolds, The Arab Spring: Pathways of Repression and Reform (New York: Oxford University Press, 2014).
} 
joined the ranks of armed rebellion, military repression kept leaders in power until foreign intervention tipped the balance. ${ }^{37}$ In all six cases, the armed forces intervened on the ground as part of the government response to popular protests. In most cases, the military used large-scale violence against civilians. Nonviolent political transitions were possible only where soldiers limited their use of force.

Many discussions of the Arab Spring have framed the military response as a binary: soldiers either defended the regime or championed the revolution. In reality, when armies confronted the Arab Spring, they responded not only with loyalty or desertion, but with a variety of strategies to manage and restore public order. Organizational culture offers a lens to explain this diversity of responses to popular uprisings, illuminating the varied roles played by soldiers in the Arab Spring.

Like Tunisia, Egypt and Syria both experienced massive anti-regime protests during the Arab Spring, but with far different outcomes. Despite the superficially similar role of the Tunisian and Egyptian armies in the Arab Spring, the actions they took during the 2011 uprisings were fundamentally different. Instead of neutrality, the Egyptian Armed Forces responded to the uprising by forcing the president from power and asserting military control over the ensuing political transition. Meanwhile, the Syrian Armed Forces, despite many similarities to their Egyptian counterparts, took the opposite approach to the Arab Spring demonstrations, applying unrestrained military force to suppress them. The brutality of the military response in Syria led not only to the fracturing of the armed forces, but also to an armed uprising against the government. In each case, the military followed a doctrine for domestic crises established over decades of experience.

Both Egypt and Syria boast large and well-trained armies, and both militaries are seen as highly politicized. While Tunisia is considered a classic case of a professional, non-political military, Egypt and Syria are paradigmatic examples of militaries based on patronage and ethnicity, respectively. In Egypt, the military controls a substantial share of the national economy, which has helped to subsidize a military budget above $\$ 4$ billion annually since 2006 (including around $\$ 1$ billion from US military aid). Retired officers, too, participate in the military's vast economic empire, reaping substantial financial rewards after their years of service. Syria's military is also active in industrial production and construction, providing material benefits to officers. However, the Syrian armed forces are best known to analysts for their ethnic composition. As in the civilian government, the minority Alawi sect holds a disproportionate share of power and influence within the military. Sunni Arabs, the majority ethnic group in Syria, are severely underrepresented among the top brass and in elite units. Before the Arab Spring, conventional wisdom held that patronage in Egypt and ethnic ties in Syria would guarantee the loyalty of the armed forces to the regime and the political status quo. In 2011, this conventional thinking failed in Egypt. Although the outcome in Syria was consistent with prior expectations, the lens of organizational culture can help explain how ethnicity came to play the role it did in the Syrian armed forces. Moreover, while institutionalized ethnic bias contributed to the Syrian military's doctrine of combat, the army's historical behavior is inconsistent with the standard ethnicity argument.

As compared with Tunisia, both the Egyptian and Syrian armies played a larger historic role, since

\footnotetext{
${ }^{37}$ Libya's Muammar Gaddafi lost power only through external military intervention by NATO, which overwhelmed the government's remaining military forces. Yemen's Ali Abdullah Saleh relied on military repression to survive one year in office after protests began. He was forced out under Saudi pressure while receiving medical treatment in the United States.
} 
independence, in their countries' political and economic life. Many of the defining moments in Egyptian and Syrian history cast the armed forces in central roles, for example the catastrophic defeat both nations suffered in the Six Day War against Israel, and the massacre at Hama, Syria, in 1982. The two countries, which had even been joined in a political union during a critical period from 1958 to 1961, shared comparable levels of professionalism but reacted in different ways to the challenge of the Arab Spring. I argue that a critical difference between Egypt and Syria was the military doctrine for domestic intervention that had developed in each country from the 1970s to the 2000s. Where the Egyptians' doctrine of control dictated that officers seize power at the regime's expense, the Syrians' doctrine of war dictated an all-out military offensive against an uprising they viewed as an existential threat to military and regime alike.

By contrast, the Tunisian army's restraint toward protesters allowed the revolution to succeed, regardless of officers' political preferences. As such, Tunisia represents a "best case" scenario for civil-military relations during revolution. In the next section, I detail the historical evolution of military organizational culture in Tunisia and demonstrate its influence on protest response during the Arab Spring.

\section{The Tunisian Army: A Culture of Restraint}

For the 338 killed and 2,174 wounded, their families and friends, and those who stood beside them terrorized as the police gunned down protesters, Tunisia's 14 January revolution was not peaceful. Yet on that day, the revolutionaries succeeded in ousting the country's autocratic president of twentythree years without the force of arms. The key to their success was the restraint of the army, which did not join the police in suppressing the anti-regime protests that would ultimately topple Ben Ali and lead to the country's first free and fair elections in history. This military response - unique in the Arab world - defies simple explanation, yet it played a critical causal role in the success of the revolution.

Since the revolution, scholars have worked to make sense of the Tunisian army's surprisingly positive role. Most explain the army's response as a result of either incapacity or disloyalty, motivated by professionalism, ${ }^{38}$ organizational interests, ${ }^{39}$ or personal grievances against the civilian regime. ${ }^{40}$ Upon closer inspection, however, we see that the army was neither disloyal nor incapacitated, but genuinely neutral. As late as mid-January, the military still had the strength to crush the revolution by force, had it chosen to defend Ben Ali at all costs. ${ }^{41}$ Instead, soldiers stood impassively in front of government buildings, leaving demonstrators and rioters to clash with the police. At the same time, the Tunisian military did not force Ben Ali from office, and senior military officers never sought power for themselves during the revolution, despite ample opportunity to take

\footnotetext{
${ }^{38}$ Bellin, "Reconsidering."

${ }^{39}$ Risa Brooks, "Abandoned at the Palace: Why the Tunisian Military Defected from the Ben Ali Regime in January 2011," Journal of Strategic Studies 36, no. 2 (February 27, 2013): 205-20, doi:10.1080/01402390.2012.742011.

${ }^{40}$ Hicham Bou Nassif, "A Military Besieged: The Armed Forces, the Police, and the Party in Bin 'Ali's Tunisia, 1987-2011," International Journal of Middle East Studies 47, no. 1 (February 2015): 65-87, doi:10.1017/S0020743814001457.

${ }^{41}$ Brigadier General Mohamed Ali El Bekri (former Inspector General of the Armed Forces), interview by the author, December 3, 2015. All ranks refer to retired officers of the Tunisian Army unless otherwise noted.
} 
advantage of the situation. ${ }^{42}$ Nor did the army refuse Ben Ali's orders to fire on protesters, because explicit orders to do so never came. ${ }^{43}$ Instead, army officers consistently adhered to their organization's culture of political neutrality, limiting their response to order maintenance operations and avoiding confrontations with protesters until after Ben Ali fled Tunis on January 14.

The case study proceeds as follows. First, I discuss the foundation of the Tunisian armed forces at independence and the initial sources of its culture. I identify three primary sources: the design of coercive institutions during the colonial era, the role of the military in securing national independence, and the relationship between the military and the hegemonic, postcolonial political party. Next, I explore how historical experience induced gradual shifts in the military's culture in favor of political restraint. Tracing the army's history in each of these areas, I describe how soldiers' ideas about neutrality and restraint were reinforced by their experience, and how these ideas were internalized, routinized, and formalized prior to 2010. Finally, I establish the role of culture in the army's response to the revolution, which promoted nonviolence and enabled the peaceful transfer of power on January 14 and afterwards.

\subsection{Foundations of Military Culture}

When a new postcolonial military is created, its initial culture derives principally from three sources: the design of coercive institutions under colonial rule and in the first years of independence, the role of soldiers in obtaining and securing national independence, and the relationship between the military and the ruling political party. From the French protectorate, Tunisia inherited a small and impotent conscription army alongside a robust civilian bureaucracy, establishing a civil-military (im)balance that persists to this day. Armed resistance played little role in securing Tunisia's independence, so civilians like Habib Bourguiba, considered the founding father of the Tunisian Republic, and his Neo-Destour party monopolized the postcolonial political scene. As president, Bourguiba established a personalistic, single-party regime - asked about Tunisia's political system, he once remarked, "The system? What system? I am the system!" 4 - and banned soldiers from the Neo-Destour, enforcing a separation of military and civilian roles in the new regime. Together, these foundations established an initial military culture that tended toward nonintervention, but was not yet fully committed to restraint.

\subsubsection{Institutional Origins}

The Tunisian Armed Forces (al-Quwwāt al-Musallaḥa al-Tūnisiyya) were established by decree on June 30, 1956, as the country was released from French colonial "protection." 45 While technically a new organization, the national army was built on the institutional foundations of the conscription-

\footnotetext{
42،General Ammar: I refused the coup in Tunis [rafị̣tu al-' inqilāb fī tūnis]," Al-Jazeera, November 6, 2015. Ammar even claimed afterward that Ben Ali's cabinet had implored him to seize power himself, but that he refused.

${ }^{43}$ Jean-Baptiste Gallopin, "Dilemma and Cascades in the Armed Forces - The Tunisian Revolution," Democracy and Security 15, no. 4 (October 2, 2019): 16-17, doi:10.1080/17419166.2019.1643324.

${ }^{44}$ Cited in Clement Henry Moore, Tunisia Since Independence: The Dynamics of One-Party Government (University of California Press, 1965), 41.

45 “Décret du 30 juin 1956 portant institution de l'Armée Tunisienne,” JORT 1956, № 52.
} 
based army France had built to contribute Tunisian troops to its foreign wars. ${ }^{46}$ The new army incorporated not only the Beylical Guard, but also some soldiers transferred from the French Army. Beginning in the colonial era, the national service (i.e., conscription) has formed a fundamental tie between the army and society. National service was formally established in 1830 under Ahmad Bey, but was rarely enforced until the 1880 s, under the French protectorate, when a standing army was finally established. ${ }^{47}$ French authorities then leveraged Tunisia's de jure conscription policy to provide auxiliary infantry to assist in the two World Wars in Europe and in the Rif War in Morocco. ${ }^{48}$ Casualty rates among Tunisian conscripts were enormous, and Tunisian families came to equate military service with virtually certain death. Long after independence, the Tunisian population continued to view conscription in these colonial terms, as the sacrifice of a son, not as an act of citizenship. $^{49}$

Since independence, every Tunisian male citizen has been subject by law to mandatory military service. Although only a small percentage of eligible young men actually perform their required military service, one-year conscripts comprise the majority of the country's armed forces. Beyond the professional officer corps, the army has long consisted of average young men from across the country, performing a civic duty often out of lack of better options. ${ }^{50}$ Despite the somewhat coerced nature of national service, this influx of young citizens into the army's ranks each year creates a shared identity between the army and the public, in a way that voluntary service-whether in a professional army or police force-does not.

Officers, too, represented a diverse cross-section of Tunisian society. After an open, nationwide call for applications, a group of young men was selected in 1956 to train at the prestigious French Special Military School at Saint-Cyr Coëtquidan. The initial class, who would become the core of the military elite for a generation, was known as the "promotion Bourguiba." The nickname, an homage to the president, reflected the cadets' devotion to both the man and his nationalist politics. ${ }^{51}$ Members of this class played an enormous role in the development not only of the army, but also of the civilian state. The class included, among other military and civilian leaders, one future governor, seven ambassadors, and three government ministers, including Ben Ali. ${ }^{52}$ From its first class of cadets, the officer corps represented the country's socioeconomic and regional diversity, which has helped the army to foster its public image as a representative of the Tunisian people. ${ }^{53}$

Following the model of the French administration, Tunisia's political leaders relied on a pervasive, centralized system of surveillance to control political dissent. ${ }^{54}$ Consistently high unemployment

\footnotetext{
${ }^{46}$ Allison Spencer Hartnett, Nicholas J. Lotito, and Elizabeth R. Nugent, "The Colonial Origins of Coercive Institutions in MENA" (Working paper, Working paper, 2018).

${ }^{47}$ Lisa Anderson, The State and Social Transformation in Tunisia and Libya, 1820-1980. (Princeton: Princeton University Press, 1987), 142-43.

${ }^{48}$ Kamel Morjane (Former Minister of Defense), interview with the author, May 26, 2016.

${ }^{49}$ Colonel Major Fawzi Aloui (Former Director General of Prisons and Rehabilitation), interview with the author, May 25, 2016.

${ }^{50}$ L. B. Ware, "The Role of the Tunisian Military in the Post-Bourgiba Era," Middle East Journal 39, no. 1 (1985): 39.

${ }^{51}$ Boubaker Ben Kraïem, Naissance d'une armée nationale : la Promotion Bourguiba (Tunis: Maison d'Edition de Tunis, 2009), 51-52.

${ }^{52}$ Ibid., 206-7.

${ }^{53}$ Ibid., 12.

${ }^{54}$ Béatrice Hibou, The Force of Obedience: The Political Economy of Repression in Tunisia (Malden, MA: Polity
} 
rates throughout Tunisia's modern history have facilitated recruitment into the ranks of the domestic national guard and national security police, which converted this surplus of inexpensive labor into a massive and pervasive surveillance and policing apparatus Anderson. ${ }^{55}$ As a result, the military has never played a role in day-to-day security operations in Tunisian cities and towns.

In sum, the Tunisian Armed Forces were designed from their creation to serve clearly delineated roles and missions, which did not include domestic intervention. ${ }^{56}$ Despite this, popular uprisings blur the lines between national security and regime security and inevitably raise the specter of military intervention. From a legal standpoint, early Tunisian laws designated the armed forces as a backup to the internal security forces in cases of extreme need. Order maintenance, as such missions are described, has always been a secondary role for the Tunisian military. ${ }^{57}$ By law, "The Minister of National Defense is responsible... to participate in the maintenance and the restoration of order by the employment of the Armed Forces, when it is legally required by the competent civil authorities." 58 Accordingly, domestic interventions by the army have been rare, occurring only a handful of times before 2011, and require the president to declare a state of emergency and explicitly request military intervention. ${ }^{59}$ Nevertheless, Tunisian law has always left the question of military intervention up to the president, leaving open the possibility of using soldiers to repress anti-regime protests.

\subsubsection{Role in National Independence}

At independence the national myth, or common story of how independence was won, plays an important role in legitimating the institutions of the nascent state. ${ }^{60}$ Thus, the role the army played in winning national independence helps determine the army's initial level of political legitimacy. Unlike in neighboring Algeria, "Tunisian independence was not won by an army, but by politics, so the army had no legitimacy except by the constitution."61 Since few, if any, soldiers could claim to have fought for Tunisia's independence, the new armed forces had no political legitimacy of their own. On the other hand, Habib Bourguiba won enormous personal legitimacy for his role in securing independence via negotiation, and he quickly consolidated power in a "presidential monarchy," backed by the hegemonic Neo-Destour Party.

The circumstances of Tunisian independence therefore empowered Bourguiba with a deep personal legitimacy, while depriving the military of any claim to political authority. Bourguiba's political philosophy focused on modernization, meaning he directed the state's limited resources toward education and economic development, rather than military power. ${ }^{62}$ From independence, the military

\footnotetext{
Press, 2011).

${ }^{55}$ The State and Social Transformation in Tunisia and Libya, 1820-1980., 236.

${ }^{56}$ Officially, the army's missions are national defense, disaster response, and occasionally contributing to economic development projects and infrastructure.

${ }^{57}$ As used in Tunisia, the term "maintien de l'ordre" also encompasses the broader idea concepts of law enforcement and the policing of public space.

58 “Décret N 75-671," JORT 1975.

${ }^{59}$ Ben Kraïem, Naissance d'une armée nationale, 195-98.

${ }^{60}$ Clement Henry Moore, Politics in North Africa: Algeria, Morocco, and Tunisia (Boston: Little, Brown, 1970), chap. 2.

${ }^{61}$ Colonel Major Mahmoud Mzoughi, interview with the author, November 4, 2015.

${ }^{62}$ Moore, Tunisia Since Independence, 41-45.
} 
budget was and remained unusually low by regional standards. ${ }^{63}$ Bourguiba spurned the purchase of expensive weapons systems and other military hardware, and directed the armed forces to invest in education and training. The army also took full advantage of opportunities to train its officers abroad at no cost to the Tunisian state. Many officers considered their treatment - "ridiculously low" pay and insufficient equipment ${ }^{64}$ - part of a persistent strategy on the government's part to "marginalize" the army. ${ }^{65}$ Nevertheless, Bourguiba's emphasis on training rather than equipment encouraged an emphasis on skill rather than prestige in the officer corps and set a precedent that continues to the present day.

\subsubsection{Relation to the Ruling Party}

Under the edicts of Habib Bourguiba, the military was disenfranchised and banned from membership in any organization. In particular, soldiers were banned outright from all political activities and memberships, even within the ruling Neo-Destour Party. ${ }^{66}$ The military elite maintained some links to civilian politics, and were occasionally appointed to civilian positions in the MoI or as regional governors, but not a single military man was appointed to a cabinet-level position until Ben Ali in 1987, who had by then spent the majority of his career in the civilian security administration. ${ }^{67}$ Thus, Bourguiba imposed a policy of apoliticism that effectively discouraged political engagement by the military elite, and even private political discussions became rare within the officer corps. ${ }^{68}$ With these efforts, the Bourguiba regime largely succeeded in removing the military as an actor in elite politics. The "republican ethos," a nationalist ideology propagated within the armed forces, encouraged soldiers to define their role and mission as defending the republic instead of encouraging loyalty to a particular leader or political party. Soldiers were and are completely banned from joining political or religious associations of any kind, and they are discouraged from expressing political opinions either within the military hierarchy or in public. Despite this formal apoliticism, however, the military remained active supporters of the government in power and were at the president's disposal to maintain the internal security of the country. Moreover, the Tunisian armed forces remained heavily dependent on political elites to approve their promotions, budgets, and operations, thus weakening their institutional autonomy from the regime. ${ }^{69}$

The non-political model of Tunisian civil-military relations was consolidated in the 1960s, at a time when coups d'état were a common feature of Arab politics. Regional leaders like Nasser in Egypt, Qasim in Iraq, the Ba'thists in Syria, and Boumédiène in Algeria had all come to power by coup d'état, and coups were occurring more frequently in the Middle East than in any other region. ${ }^{70}$ Bourguiba was deeply concerned with avoiding a similar fate, especially after the Free Officers' Revolt in Egypt in 1952. ${ }^{71}$ His concerns soon found justification. In 1962, a small group

\footnotetext{
${ }^{63}$ Anderson, The State and Social Transformation in Tunisia and Libya, 1820-1980., 236.

${ }^{64}$ Interview with a senior army officer, November 2015.

${ }^{65}$ Ware, "The Role of the Tunisian Military in the Post-Bourgiba Era," 39.

${ }^{66}$ Ibid., 37.

${ }^{67}$ Bellin, "Reconsidering," 146n32.

${ }^{68}$ Interviews with senior officers.

${ }^{69}$ This observation runs counter to classifications of Tunisian military as highly institutionalized (cf. Bellin, "Reconsidering," 129).

${ }^{70}$ Elizabeth Picard, "The Arab Military in Politics," in The Arab State, ed. Giacomo Luciani (Berkeley, CA: University of California Press, 1990), 190.

${ }^{71}$ Moore, Tunisia Since Independence, 197n46.
} 
of soldiers attempted to overthrow Bourguiba, but the plot was discovered in the planning stages and the plotters were harshly punished: most were executed within a month. ${ }^{72}$ The plot did not enjoy widespread support within the army, and did not indicate a broader politicization in the ranks - to the contrary, most military officers remained uninvolved in politics. Nevertheless, the coup attempt hardened the regime's approach to depoliticizing the military and repressing political dissent more generally.

When Ben Ali, a career security officer and former brigadier general in the army, took power, observers in Tunisia and abroad believed that the army was poised to play a much greater role in Ben Ali's new regime. ${ }^{73}$ But despite starting his career as a military officer, Ben Ali took office with a wary eye turned toward his former comrades. Rather than bringing the military closer to the ruling party (now rebranded as the Rassemblement Constitutionnel Démocratique, RCD), Ben Ali's rise to power heralded a turn for the worse in officers' fortunes. In 1991, hundreds of military officers were suddenly arrested and accused of illegally supporting the Islamist Ennahda movement. The incident, known as the Barraket Essahel affair, marked a turning point in the army's estrangement from the regime, reinforcing the army's political neutrality prior to $2010 .^{74}$ The case involved the sudden arrest of 264 soldiers accused of organizing an Islamist-leaning coup d'état against the president. The charges were purely political: by implicating both the military and Islamists in a plot against the state, Ben Ali's regime had a free hand to strike against both threats at once. ${ }^{75}$ The arrests corresponded with a period of excluding Army officers from top political appointments such as positions in the civilian MoI, to which Ben Ali had appointed military officers during the first years of his presidency - indicating his desire to diminish the Army's political influence within the regime. ${ }^{76}$ Some military officers who were uninvolved in the affair described an atmosphere of fear in the officer corps, fueled by concerns about guilt by association or false accusations. ${ }^{77}$

In the 1990s, the Ben Ali regime became increasingly tarnished with a reputation for corruption. ${ }^{78}$ Yet while the regime's corruption was seen to extend to the police forces, the military was not directly implicated in any form of corruption. ${ }^{79}$ The relative absence of corruption in the military may be interpreted as a sign of its political restraint, but it also indicates military officers' distance from real political power during this period. Widespread allegations of rampant corruption within Ben Ali's family and associates also contributed to some military officers' desire to distance themselves

\footnotetext{
${ }^{72}$ Moncef El Materi, De Saint-Cyr au Peloton d'Exécution de Bourguiba : La Tentative de Coup d'Etat de 1962 en Tunisie (Tunis: Arabesques Editions, 2014).

${ }^{73}$ L. B. Ware, "Ben Ali's Constitutional Coup in Tunisia," Middle East Journal 42, no. 4 (1988): 587-601.

${ }^{74}$ Noureddine Jebnoun, "In the Shadow of Power: Civil-Military Relations and the Tunisian Popular Uprising," The Journal of North African Studies 19, no. 3 (May 27, 2014): 302, doi:10.1080/13629387.2014.891821.

${ }^{75}$ The government's allegations were improbable at best. A senior officer in charge of military security at that time told me that the supposed planning meeting simply could not have occurred. The sleepy town of Barraket Essahel, he said, did not have a building large enough to hide 200-some conspirators. After the revolution, Ben Ali was convicted in absentia for his role in the torture of military officers involved in the Barraket Essahel affair (Le Monde, "Tunisie : Ben Ali condamné en appel pour des actes de torture," Le Monde, April 7, 2012, http://www.lemonde.fr/tunisie/artic le/2012/04/07/tunisie-ben-ali-condamne-en-appel-pour-des-actes-de-torture_1682193_1466522.html). The officers themselves were rehabilitated to their military rank and pensions, but prevented from re-joining the military.

${ }^{76}$ Bou Nassif, "A Military Besieged," 70-71.

${ }^{77}$ Commandant Alia Mzoughi, interview with the author, November 4, 2015.

${ }^{78}$ Peter J. Schraeder and Hamadi Redissi, "Ben Ali’s Fall,” Journal of Democracy 22, no. 3 (July 9, 2011): 9, doi:10.1353/jod.2011.0047.

${ }^{79}$ Mahmoud Mzoughi, interview.
} 
from the president and his political circles. ${ }^{80}$ In consequence, the armed forces became increasingly estranged from the RCD and the political leadership during the Ben Ali period. ${ }^{81}$ While the Tunisian military, unlike highly political armies elsewhere in the region, was relatively apolitical from its founding, the 1990s nevertheless brought a further weakening of the army's relationship to the ruling party.

\subsection{Past Interventions}

Soldiers' experience interacting with citizens during domestic interventions generates innovation in the army's cultural norms of intervention. Because military intervention in response to protests or riots has been historically rare, each intervention on Tunisian territory has served as an influential guide for cultural change. The lessons learned from a small number of domestic interventions in the 1970s and 1980s, which nevertheless came at a critical time in the professional development of the army as a whole, therefore drove a process of major cultural change, which ultimately created the cultural commitment to neutrality observed during the 2011 revolution. In this section, I rely on personal interviews and declassified, contemporaneous diplomatic notes to construct a timeline of the Tunisian army's cultural development from independence to 2011.

Since its creation in 1956, the army has generally maintained positive relations with society, but during crises, officers worried that tensions would erupt and the situation would get out of control. In one officer's words, "We were always afraid that a confrontation would explode and the situation would become uncontrollable." 82 When the army, following established protocol, is brought in to back up the security forces, soldiers can either try to calm the situation or escalate the use of force. In the army's first post-independence intervention in 1978, the army intervened violently, killing and injuring civilian demonstrators. ${ }^{83}$ After 1978, however, officers' strategy for domestic intervention shifted away from overwhelming force and toward peacefully defusing the situation.

\subsubsection{Black Thursday, 1978}

The military's direct involvement in domestic politics peaked in the final decade of Bourguiba's presidency, when the army carried out its two largest domestic interventions of the twentieth century. Despite being formally apolitical and largely disengaged from elite politics, the Tunisian Army initially accepted a primary role in order maintenance through the 1970s. The army's first major intervention came during the fall and winter of 1977 and 1978, culminating January 28 on a day known as "Black Thursday." As the government inaugurated a second Five-Year Plan in 1977, increasing Tunisia's dependence on foreign investment, tensions mounted between the country's largest trade union, the Union générale de travailleurs tunisiens (UGTT) and the hegemonic Parti Socialiste Destourien (PSD). Receiving only minor concessions from the government, UGTT leader Habib Achour resigned from the political bureau of the PSD and called a nationwide general strike to begin in January 1978, its first since independence. The union coupled economic

\footnotetext{
${ }^{80}$ Khalfi, interview.

${ }^{81}$ Bou Nassif, "A Military Besieged."

${ }^{82}$ Colonel Major Ahmed Ghiloufi (Former senior military instructor), interview with the author, October 30, 2015.

${ }^{83}$ Nigel Disney, "The Working Class Revolt in Tunisia," MERIP Reports, no. 67 (1978): 13-14, doi: $10.2307 / 3011401$.
} 
grievances with demands for political pluralism, highlighting the UGTT's position as the only capable challenger to the PSD, as it had been since $1956 .{ }^{84}$ As the police, army, and a little-known PSD militia clashed with demonstrating students and workers, the strike devolved into violent rioting. This was the first case in post-colonial Tunisia where protests escalated beyond the capacity of the police.

Responsibility for the government's response to these protests fell to Director General of National Security Zine el-Abidine Ben Ali. Under Ben Ali's direction, the police and national guard used live ammunition to disperse public gatherings. As the strike gained support across the country, protesters began to fill streets in towns and villages across the country. Bourguiba then declared a state of emergency and instructed the Minister of Defense to order the army into the streets to disperse the protests. According to a former MoD spokesman, the army chief's close ties to the political elite influenced his decision to intervene:

In 1978, the army chief was too close to the politicians, so when they asked him to intervene, he sent the army into the streets. This led to [the army] firing into crowds, which is contrary to the principles of the army. ${ }^{85}$

Sending armed conscripts into the street with simple orders to put down the protests virtually guaranteed a violent outcome. One senior officer, who later served as inspector general of the armed forces, observed, "The army went out against riots, stupidly with weapons, but they were not prepared for riots. You have armed soldiers facing provocation without any training for this." ${ }^{86}$ The official death toll was forty-seven, but most sources put the number as high as two hundred. ${ }^{87} \mathrm{Al}$ though the forceful combined response of the police and army ended the protests quickly, the state's brutality created a negative public reaction. ${ }^{88}$

The military's subsequent actions demonstrated an acute sensitivity to the public criticism of the army's role in putting down the unrest. Once the protesters were subdued, the government and army moved to protect their image. Unofficial casualty figures, circulating on international news wires, were censored from the national press, which ran only the improbably low government figures. ${ }^{89}$ On January 19 Hassib Ben Ammar, director of a political newspaper and an ex-Minister of Defense, had published an editorial criticizing the army's role in repressing protests early in the conflict; he was quickly brought before a military tribunal, which convicted him on charges of defaming the institution of the army. With the newspapers censored to prevent negative coverage, Bourguiba delivered a public address thanking and congratulating the armed forces for restoring order. ${ }^{90}$

Yet the military itself was deeply shaken by the events. A week after the events, the US Ambassador reported that "Officers, from Army Chief of Staff General Excheikh (sic) on down, are still shaken up," while junior officers appeared "confused" and ill-informed about the events and their

\footnotetext{
${ }^{84}$ Kenneth J. Perkins, A History of Modern Tunisia, 2nd ed. (New York: Cambridge University Press, 2014), 167.

${ }^{85}$ Colonel Major Mokhtar Ben Nasr, Interview with the author, November 25, 2015.

${ }^{86} \mathrm{El}$ Bekri, interview.

${ }^{87}$ Anderson, The State and Social Transformation in Tunisia and Libya, 1820-1980., 242.

${ }^{88}$ Disney, "The Working Class Revolt in Tunisia," 14.

${ }^{89}$ Department of State, "New York Times Articles," Wikileaks Cable: 1978STATE024708_d, dated January 31, 1987.

${ }^{90}$ Embassy Tunis, "Bourguiba Congratulates Army," Wikileaks Cable: 1978TUNIS00967_d, dated February 8, 1978.
} 
causes. ${ }^{91}$ Many officers, both junior and senior, regretted their involvement in Black Thursday and were determined to avoid being drawn into another political confrontation with the public. ${ }^{92}$ The US Embassy monitored the situation closely, interviewing senior government officials and military officers of all ranks. The American ambassador reported strong dissatisfaction among the armed forces: "They see themselves as being blamed by many Tunisians for shooting other Tunisians, a decision over which they had no control."93 Later, as these officers reached positions of influence within the military, they would make sure that the next time a domestic crisis threatened the government, the military itself would have a measure of control over the decision to intervene.

\subsubsection{Steps toward Restraint}

In 1980, an incident known as the Gafsa Affair helped push the military's focus back to traditional defense, rather than politics. In the 1970s, tensions had escalated with neighboring Libya and its volatile leader, Muammar Gaddafi. On April 1979, the Minister of Defense told the US Ambassador that Tunisian defense strategy was "focussed almost exclusively on the threat from Libya." 94 By the end of that year, social unrest had begun to reappear, echoing the general strike of 1978. Seeking to take advantage of the political turmoil, Gaddafi had trained a group of Tunisian militants in commando tactics and helped them infiltrate back into Tunisia, hoping to instigate an uprising that could topple Bourguiba's government. ${ }^{95}$ On the night of January 26, 1980, a group of about thirty commandos launched a surprise raid on the southern city of Gafsa. ${ }^{96}$ Thanks in part to intelligence warnings of an impending attack, the Tunisian Army competently repelled the attack, limiting civilian casualties while retaking control of the city and preventing the escape of the assailants. ${ }^{97}$

The Gafsa Affair forced Bourguiba to admit the necessity of an army to defend Tunisia's borders. ${ }^{98}$ As a result, he grudgingly augmented the military's budget for provisions and equipment. ${ }^{99}$ Nearly all of the military's new resources were spent countering a series of cross-border raids launched by Gaddafi over the coming years, so the change did not massively increase the resources available to the military. ${ }^{100}$ However, the incident demonstrated that Tunisia, though extremely secure by regional standards, was not without need of a robust national defense. Finally, public praise of the army's performance provided a stark contrast to the wave of criticism that had followed the army's last intervention. As a result, the material strength of the military was actually increasing through the 1980s. Rather than weakness, the non-interventionist policy of the Tunisian army must

\footnotetext{
${ }^{91}$ Embassy Tunis, "Reaction of Tunisian Military to Use of Armed Forces against Rioters," Wikileaks Cable: 1978TUNIS00831_d, dated February 2, 1978.

${ }^{92}$ Ware, "The Role of the Tunisian Military in the Post-Bourgiba Era," 39.

${ }^{93}$ Embassy Tunis, “Assessment of Tunisian Situation," Wikileaks Cable: 1978TUNIS01109_d, dated February 13, 1978.

${ }^{94}$ Embassy Tunis, “Tunisian Defense Strategy-Meeting with with [sic] Minister of Defense Farhat," Wikileaks Cable: 1979TUNIS03246_e, dated April 20, 1979.

${ }^{95}$ Perkins, Modern Tunisia, 169.

${ }^{96}$ Boubaker Ben Kraïem, "L'affaire de Gafsa en 1980 : Témoignage du Colonel Boubaker Ben Kraiem.” Site officiel de Moncef El Materi. Accessed on: Dec. 3, 2015.

${ }^{97}$ A senior officer who did not wish to be named, Dec. 6, 2015.

${ }^{98}$ Perkins, Modern Tunisia, 170.

${ }^{99}$ Ware, "Ben Ali's Constitutional Coup in Tunisia," 594.

${ }^{100}$ Interview with a senior military officer, November 7, 2015.
} 
be understood as a choice. As one commander explained, "During the three crises of 1978, 1980, and 1984, the regime depended on the army. In other countries in this situation you would have seen the army take power, but the Tunisian army does not involve itself in politics. This is a point of pride for us." 101

When nationwide bread riots broke out four years later, avoiding bloodshed at the hands of the army had become a top priority, demonstrating how culture had already begun to shift following the disastrous events of 1978. The "bread riots" of January 1984 were set off by a severe reduction in government subsidies for bread and semolina (i.e., couscous) at the behest of the IMF and World Bank. ${ }^{102}$ As riots broke out, Bourguiba recalled Ben Ali from an ambassadorial post in Poland, to again oversee the brutal suppression of the protests in his former role of director general of national security. Ben Ali again ordered the police and national guard to fire on crowds of unarmed demonstrators, and the MOI called for assistance from the military. ${ }^{103}$ With many officers already concerned about the reputational costs of firing on unarmed civilians, some commanders leading the 1984 intervention sought to reduce casualties. One regimental commander described his approach as follows:

We had declared a state of emergency, the highest level of emergency, at which point the Army is charged with maintaining order. I had no direct experience with this, but I had the lessons and ideas from my comrades who had participated in $1978 \ldots$ I said to myself the most important thing is that no one be killed by the Army's bullets. I wanted the civilian leadership stay in place, not to replace it with military government. ${ }^{104}$

Although many commanders who had experienced the disaster of 1978 looked for creative ways to diffuse confrontations without violence, others followed orders and opened fire. Several army units participated with the police and national guard in firing on demonstrators, killing dozens of civilians. This time, the military crackdown created such a severe public backlash that Bourguiba was forced to reverse himself. He immediately restored the subsidies and implausibly claimed that his prime minister had implemented the cuts without the president's knowledge. ${ }^{105}$

Officers' involved in these order maintenance operations recognized that they were doing political work by confronting crowds of demonstrators chanting slogans against the political regime. They chafed against their deeply held conviction that the army should not involve itself in politics, and their immediate response was to minimize their political involvement. The officers also recognized that the protesters were angry with politicians, and perhaps the security forces, but not with the army. Following the 1984 crisis, a group of senior officers informed Prime Minister Mohammed Mzali that they would not support future orders to deploy against unarmed civilians. ${ }^{106}$ Another group of senior officers informed the US Embassy at the time that they are "uncomfortable with

\footnotetext{
${ }^{101}$ Colonel Major Hedi Tajani, interview with the author, May 18, 2016.

${ }^{102}$ Perkins, Modern Tunisia, 172.

${ }^{103} \mathrm{Jim}$ Paul, "States of Emergency: The Riots in Tunisia and Morocco," MERIP Reports, no. 127 (1984): 3-6, doi: $10.2307 / 3010972$.

${ }^{104}$ Colonel Major Moussa Khalfi (Former Director of Military Security), interview with the author, November 6, 2015.

${ }^{105}$ Perkins, Modern Tunisia, 173.

${ }^{106}$ The officers described their conversation with the prime minister to the US military attaché, whose report circulated within the CIA.
} 
assignments to put down civil unrest and fear that Mzali will call on them again."107 Although Mzali's government made efforts to strengthen the internal security forces, the CIA assessed in May of 1984 that these efforts were likely to be insufficient, requiring the government to again depend on the Army "to put down unrest, which may prompt the officer corps to throw its weight behind a replacement and the rank-and-file to perform in a lukewarm fashion." This experience provided the insight and motivation for innovation in the way the army would prepare to respond to future political crises. The generation of military officers whose first command experiences came in the popular uprisings of 1978 and 1984 would later lead the army's cultural shift toward nonintervention. Their experience struggling to control rioting crowds without resorting to lethal force taught this cadre of officers the value of nonviolent tactics, as well as the steep reputational costs the army risked incurring if the situation got out of hand.

\subsection{Embracing a Culture of Restraint}

In the 1970s and 80s, the Tunisian military's experience with domestic interventions solidified the organization's cultural disposition to restraint and nonviolence. As officers took lessons from their education and experience, they internalized the core concepts of a non-interventionist culture. In my interviews, many senior officers referred to the uprisings of 1978 and 1984 to explain why the culture of the Tunisian Army changed. A few even mentioned the Romanian revolution of 1989 and the uprising at Timișoara, where the army's intervention had failed when soldiers began firing at unarmed civilians, leading to total chaos, many civilian casualties, and eventually the downfall of the Ceauşescu regime. ${ }^{108}$ To Tunisian officers, examples like these offered a bloody case study in how not to intervene. ${ }^{109}$ From personal and historical experience, they recognized that shooting civilians can be costly to the military. As Bellin observes, "shooting on civilians... can spell serious damage to the military's core institutional interests: cohesion, discipline, prestige, and legitimacy." 110 In light of these interests, the Tunisian military responded to the backlash against its 1978 and 1984 interventions by reforming its culture for domestic crises.

Recognizing the nature of the army's relationship with the population, the professional officers at the top of the military organization came to understand that they could enhance their social position and prestige by refusing to use force against civilians. According to several military officers, the army's public reputation benefited greatly from its respect for the law and abstention from use of force against the population. A retired senior military officer described the army's public relations under the Ben Ali regime as follows:

The police did not have a good reputation in the country, but the army did. Because several times the army came to help them-especially in natural disasters - the army

\footnotetext{
${ }^{107}$ Directorate of Intelligence, “Tunisia: More Troubles Ahead," FOIA Document: CIARDP85T00287R001301600001-2, May 23, 1984.

${ }^{108}$ Peter Siani-Davies, The Romanian Revolution of December 1989 (Ithaca, NY: Cornell University Press, 2007), 63-66.

109"I had in my mind what happened in Timișoara, in Romania. When the army made an intervention against people in Timișoara, they killed 80 people. Why? They were not there to kill people, but there are provocateurs. People were peacefully protesting, but someone inside the crowd fires at the army and [machine gun noises]. This is what happened in Tunisia, I'm convinced that happened." El Bekri, interview.

${ }^{110}$ Bellin, "Reconsidering," 132.
} 
had an appreciation in the population. That's very important, because we have always treated them that way. The law says that the military doesn't even have the legal ability to deal with the population. To ask someone in the street for his identity card, you must be a judicial [non-military] police officer, the law says so. ${ }^{111}$

Another officer, Col. Maj. Ben Nasr, was spokesman for the Tunisian Armed Forces during the revolution. As he explained, the army reformed itself after 1984 specifically to avoid police work and the reputational cost of confronting citizens directly:

"After [the bloodshed of 1984] the army reformed its rules and said, if we keep doing this [order maintenance], our role will be confused with the police. After that it was very strict: Under General Ammar, the army only accepted the role of defending state institutions, not intervening against the population. This is where divisions were created between the army and the politicians. Ben Ali did not agree with the army's stance." 112

Meanwhile, as the military eliminated the use of violence against protesters from its repertoire of action, the practice of nonviolence became routinized. From the army's founding, the institution stood apart from the coercive apparatus of the state. Because of the social composition and public role of the army, the public did not initially identify the army as part of the regime's coercive apparatus after independence. When Tunisia's internal security forces responded to major demonstrations under Bourguiba and Ben Ali, violence was commonplace.

But unlike the internal security forces, the army did not participate in routine state repression, nor did officers engage in the face-to-face, low-level interactions with citizens that so often lead to petty corruption and abuses of power. Thus, citizens came to expect different behavior from soldiers than from police. In interviews, several senior officers attested that throughout the army's history, crowds of protesters have tended to respond more peacefully to soldiers than to the police. One officer described the dynamic as follows:

Unfortunately the police do not have good relations [with the public] because they provoke confrontation; they use force. But the population doesn't accept that, and it's [the army's] role to calm the situation. Generally when we intervene on the ground, the population calms down. Generally, we do not allow the police direct contact with the population. We say to the security forces, 'stand back, we will handle this.' Then the police see the population calm down in front of the soldiers, and of course, still seek confrontation with the police. ${ }^{113}$

This scenario, repeated in similar form by several of my interviewees, describes strikingly positive relations between soldiers and society, based on the army's limited role in internal security. Because domestic interventions were rare, the population believed ex ante that the young soldiers, fellow citizens performing their national service, probably would not harm them. If they were afraid of military intervention, it was a fear of the unknown, not fear of a known threat as with the police.

Major labor strikes in the Gafsa mining region in 2008 further routinized the culture of restraint. As

\footnotetext{
${ }^{111}$ Interview with a senior army officer, December 5, 2015.

${ }^{112}$ Ben Nasr, interview.

${ }^{113}$ Ghiloufi, interview.
} 
protests grew, they soon overwhelmed the internal security forces, despite their use of tear gas and water cannons. ${ }^{114}$ Meanwhile, the army moved to secure key strategic sites, including the mines themselves, but ignored the escalating crisis in the streets. According to Col. Maj. Ben Nasr, the army's restraint was initiated entirely by the military itself, much to the consternation of the political leadership: "The Army decided to guard the installations, of phosphates, without intervening on the ground, or in the street to oppose the population. And that started the tensions between the Army and the political side. The president didn't appreciate that but he couldn't do anything about it, because it's the law." 115 There was no love lost between the army and the president; their relations had been fairly icy for decades, despite Ammar's deep personal loyalty to Ben Ali. Yet the Gafsa uprising may have given Ben Ali an insight into how far the armed forces had moved away from the order maintenance role, establishing a useful precedent for the revolution.

The army joined the intervention only after President Ben Ali declared a curfew on June 6. Even then, it was the internal security forces who used live ammunition to disperse the crowds, killing one and injuring twenty-one others, while the military held its fire. ${ }^{116}$ Kamel Morjane, Minister of Defense during the crisis, described the military intervention in the town of Redeyef:

The Army entered around 6 o'clock in the evening. At the beginning, [the strikers] started throwing a lot of things... but when they realized it was the Army, they started applauding. The bakers who were on strike went to their bakeries and began preparing bread for them and distributed it to the Army. Because they knew that they would not touch them. Because if [the Army is] in charge of protecting a bank, as far as [protesters] don't touch it, no soldiers will intervene. Which means for them a certain confidence: if you don't have bad intentions, the Army will not touch you. There is a sort of confidence in the fact that they don't often have contact with people, except those who come for their national service. ${ }^{117}$

To many participants on both sides, the strikes came to be seen as a precursor to the 2011 revolution. In the words of one protester, who demonstrated in both 2008 and 2011, "The revolution started here in 2008 in Moulares and Redeyef."118 The remarkable success of the military's restraint in Gafsa signaled that nonviolence had become routine within the Tunisian armed forces.

Moreover, the Tunisian army had taken explicit steps many years earlier to prepare its nonviolent response. One implication of the cultural shift was an overhaul of the army's training and tactics for public order operations. During Rachid Ammar's command of the army, the general staff worked to implement reforms in the training of soldiers for domestic interventions, focusing on defending public buildings and minimizing confrontation with demonstrators. A senior officer working on the staff at the time, Brigadier General Mohamed Ali El Bekri, described their motivations as follows: "As we took the lessons from [the past interventions], we trained people how to deal with a

\footnotetext{
${ }^{114}$ Larbi Chouikha and Éric Gobe, "La Tunisie entre la « révolte du bassin minier de Gafsa » et l'échéance électorale de 2009," L'Année du Maghreb, no. V (November 1, 2009): para. 26, doi:10.4000/anneemaghreb.623.

${ }^{115}$ Ben Nasr, interview, November 25, 2015.

${ }^{116}$ Chouikha and Gobe, "La Tunisie entre la « révolte du bassin minier de Gafsa » et l'échéance électorale de 2009," para. 29.

${ }^{117}$ Interview with the author, May 25, 2016.

${ }^{118}$ Carlotta Gall, "Tunisian Discontent Reflected in Protests that have Idled Mines," The New York Times, May 13, 2014.
} 
population in front of them. We had as a background to try the maximum to avoid civilian casualties." 119 From 2004-2010, under General Rachid Ammar, the army implemented a specific training doctrine for crowd control. A senior officer involved in the planning described these preparations as follows:

We did all that we can to protect the population because we felt that we must not, absolutely not [use force]. Because the people are asking for freedom or asking for rights, they must not be killed. It is against humanity. So we trained our people. The training and the preparation... is important to avoid shooting stupidly. Because you have weapons, you think you are allowed to kill people who are not protected. ${ }^{120}$

To mitigate the risk of a violent confrontation with protesters, the army followed a simple procedure: soldiers first delineated clear lines to the demonstrators, then refrained from interfering the protesters or responding to insults or provocations. If protesters did not fully respect the limit, soldiers would warn them by firing on a harmless, predetermined target. Force would be used only as a final resort, if protesters attempted to disarm the soldiers. El Bekri, an architect of these tactical plans, described them as follows:

One of the steps is you shoot down [into the ground]. Here, the main importance is they do not take your weapons. Because if they take your weapons they can shoot on you or on other people... Unfortunately, if you shoot sometimes ricochet can cause accidents. We take another step, to show people that the bullets can kill, in our plans we choose a place - for example if there is a big wall behind the crowd, we make a square target and fire on that target to show the population it kills, it's real bullets. Why did we do that? Because in 1978, some in the population would say, when [soldiers were] firing in the air, “Oh, it's blank ammunition. Don't worry about it! Cross the line, it's blank ammunition!" So it's one more step to show the population. ${ }^{121}$

These procedures are not intended to provide crowd control, since they do not enable soldiers to clear an occupied area, nor to disperse protesters. Moreover, the Tunisian Army does not possess if non-lethal crowd control equipment, such as batons, water cannons, or tear gas. Instead, this approach allows the army to defend a fixed point, such as a government building, without directly confronting the population. In most cases, however, the army tried to keep weapons out of the equation altogether. The director of military security in the 1990s explained the value of confronting protesters unarmed:

If you see a soldier with a weapon you think he's going to oppose you; if you see a soldier or policeman who was unarmed you think he is just doing his job. $[\mathrm{He}]$ is not going to use weapons against me. These things are very important. All the years I was in charge of military security, whenever there was a disturbance or situations like this in the country, I always kept this in mind, but above all, soldiers must not act as though they are armed, going into battle. They should act as Tunisians, explain what they are doing and try to find a solution. If you can avoid force, and especially weapons, all

\footnotetext{
${ }^{119} \mathrm{El} \mathrm{Bekri,} \mathrm{interview.}$

${ }^{120} \mathrm{El}$ Bekri, interview.

${ }^{121}$ El Bekri, interview.
} 
the better. $^{122}$

In addition to domestic training, the Tunisian army formalized its nonviolent tactics during deployments in support of UN peacekeeping missions in Cambodia, Somalia, and Rwanda, where they received high praise from UN commanders for their exceptional professionalism and exemplary contributions to multinational forces. ${ }^{123}$ According to Jane's, a highly-respected defense analysis publication, "Deployments with UN peacekeeping missions in Africa provided the essential experience and resource capabilities to fill the void left by the collapse in legitimacy and capacity of Ben Ali’s Ministry of Interior security forces in 2011."124

In conclusion, soldiers' reflections on previous interventions and their Western military education internalized the values of nonviolence and nonintervention. Restraint became routine as more and more officers exercised discretion when confronting their fellow citizens. Finally, officers' formal training and peacekeeping experience served to formalize a nonviolent repertoire of action for domestic security, which ultimately ensured the Tunisian army's peaceful and politically neutral response to the revolution.

\subsection{Responding with Restraint}

In December 2010 the tragic self-immolation of Mohamed Bouazizi, which catalyzed the revolution, took place 100 kilometers north of Gafsa in another economically-depressed city of the southern interior, Sidi Bouzid. As massive protests developed and spread throughout the country, the army avoided contact with the protesters. Instead, the Army Chief of Staff, General Ammar, ordered his forces to defend strategic sites and state institutions like the national radio, but not to go beyond this minimal mission. ${ }^{125}$ The army spokesman at the time explained that Ammar was explicitly following the rules established previously and employed on a smaller scale during the mining protests in Gafsa:

During the revolution it was the same [as in 2008]. The Army was solicited, it intervened and positioned itself at certain sensitive points and stopped there. When the army was asked, in certain places, to intervene the army said, "Look, we do not fire on the population. That's the role of the police and the National Guard." There was a dispute with the president, so the chief of staff [Ammar] wrote, "no soldier may fire on the population, no matter the situation, without prior authorization from his commander." Which is a nonsensical order in a military context, but it was to forbid firing on crowds. ${ }^{126}$

Thus, crowd control and order maintenance were left to the internal security forces under the direction of the MoI. Meanwhile, the MoD and military commanders continued to participate in crisis meetings with President Ben Ali, but neither suggested nor supported a plan to increase military involvement in the response. As protests spread across the country, the size and scope of demonstrations began to overpower police capacity. By early January, many low-ranking police officials

\footnotetext{
${ }^{122}$ Khalfi, interview.

${ }^{123}$ Mzoughi, interview.

${ }^{124}$ IHS Markit, Jane's World Armies (London, 2016).

${ }^{125}$ Jebnoun, "In the Shadow of Power," 304-9.

${ }^{126}$ Ben Nasr, interview, November 25, 2015.
} 
throughout the country had lost contact with high-ranking officials, who had turned off their cellphones. ${ }^{127}$ Citizens began attacking police stations and overrunning barricades throughout Tunisia, but the military did nothing to defend the police. ${ }^{128}$ In isolated cases, it was reported that soldiers and police even exchanged fire. ${ }^{129}$ By January 14, police authority had completely collapsed, and Ben Ali ordered Army Chief of Staff General Ammar to take control of the central operations room at the MoI. ${ }^{130}$ With the situation escalating out of control, why did the armed forces not respond in force to subdue protests?

The answer lies in the culture of neutrality the army had developed over the previous decades. As the crowds swelled in December 2010 and January 2011, the internal security forces under the MoI, not the army, deployed to confront them. As the police used deadly force against civilians, the police themselves became the target of demonstrators' rage. Protesters attacked the police in front of them at demonstrations, along with police stations and the MoI headquarters in downtown Tunis. ${ }^{131}$ The army, however, avoided engaging the protesters by only defending major government institutions and strategic sites, like the state radio station and presidential palace. ${ }^{132}$ This strategy of restraint was entirely consistent with the restrained approach army officers had developed for order maintenance after the 1978 and 1984 uprisings and had codified under General Ammar's command. In response, protesters did not target government sites defended by the army, but preferred instead to attack the major manifestation of government abuse in their own lives: the offices of the ruling RCD party and the palaces of Ben Ali and his family and allies, along with police stations. ${ }^{133}$ In this way, the army used tactical restraint to avoid engagement with the entire revolution until late on January 14, when Ben Ali fled into exile.

Once the regime fell and protesters' demands were met, the army quickly stepped in to reestablish security. Having stood by impassively for two months, the military suddenly acted firmly to restore order, demonstrating a latent capacity that was intentionally untapped during the revolution. ${ }^{134}$ In one much-publicized incident, soldiers raced to secure a large supermarket in the Tunis suburbs, arriving just in time to disperse a mob of looters descending on the giant building. ${ }^{135}$ The army had sufficient tactical capability and organizational strength to halt the looting and criminal activity

\footnotetext{
${ }^{127}$ Merouan Mekouar, "Police Collapse in Authoritarian Regimes: Lessons from Tunisia," Studies in Conflict \& Terrorism 40, no. 10 (October 3, 2017): 858, doi:10.1080/1057610X.2016.1239991.

${ }^{128}$ In the words of a senior officer interviewed by Hicham Bou Nassif, "We shed no tears when the people attacked police stations. The police were corrupt and arrogant vis-à-vis the population and the armed forces. That the military should kill civilians in order to protect the police was out of the question; whatever happened to the police, they asked for it." (Bou Nassif, "A Military Besieged," 86n79).

${ }^{129}$ These reports cannot be confirmed, but skirmishes like these between various branches of the state coercive apparatus are common during political transitions; see John Gledhill, "Competing for Change: Regime Transition, Intrastate Competition, and Violence," Security Studies 21, no. 1 (January 2012): 43-82, doi:10.1080/09636412.2012.650592.

${ }^{130}$ Sharan Grewal, “A Quiet Revolution: The Tunisian Military After Ben Ali” (Washington, DC: Carnegie Middle East Center, 2016), 5.

${ }^{131}$ ICG, "Tunisia’s Way," Middle East/North Africa Report, Popular Protest in North Africa and the Middle East (International Crisis Group, April 28, 2011).

${ }^{132}$ Brooks, "Abandoned at the Palace," 206 n5.

${ }^{133}$ Amira Aleya-Sghaier, "The Tunisian Revolution: The Revolution of Dignity," in Revolution, Revolt and Reform in North Africa: The Arab Spring and Beyond, ed. Ricardo Larémont (Routledge, 2013), 38-39.

${ }^{134}$ Jebnoun, "In the Shadow of Power," 311.

135“Carrefour, défendu par les forces de l'armée nationale, et fermeture provisoire,” Leaders (Tunis), 10 February
} 2011 . 
that proliferated after the collapse of the interior security forces. During the revolution, nine of the country's eleven prisons had been abandoned, and thousands of inmates escaped, most of whom were not political prisoners, thus presenting a serious risk for public safety and security. ${ }^{136}$ At least thirty-seven civilians were killed by the military over the next six weeks, but calm returned to Tunisia under the security guarantee of the armed forces.

A retired chief of staff of the navy later asserted, "Had the orders been given to shoot, the officer corps in its entirety would have turned against "Ammar." 137 His view reflects the extent to which restraint and nonviolence were firmly entrenched in the military's culture. On the other hand, a brigadier general of the army who worked closely with Ammar asserted to me that if Ammar had decided to crush the uprising by force, even as late as January 14, he could absolutely have done so. ${ }^{138}$ Yet the general never came close to giving such an order, even after gathering in a crisis meeting with the country's top officials on January $13 .{ }^{139}$ Instead, his soldiers hewed closely to the neutral role they had established for themselves over the past three decades. In the end, it was this culture which enabled the largely peaceful revolution of 14 January and the subsequent transition to electoral democracy.

\section{Conclusion}

Previous attempts to explain military responses to mass protest have focused on rational-strategic decision making by military leaders, driven by factors like professionalism, patronage or ethnicity. Instead, I find that organizational culture provides the best explanation for military responses to mass protests. I have argued that the origins of a military's culture trace back to the establishment of the national military, often during the colonial era. Historical factors such as the design of colonial institutions, soldiers' role (if any) in securing national independence, and the relationship between the military and the ruling political order established in the early post-colonial period establish an emergent cultural orientation in the new national armed forces. Next, the military culture evolves through practical experience, primarily from domestic interventions, such as protest response, which challenge existing ways of thinking and doing. Together, these historical processes jointly determine the military's organizational culture, shaping the beliefs and practices that soldiers will employ during their next encounter with mass protests.

In reconsidering the military responses to the Arab Spring, I find that organizational culture was critical in producing varied outcomes across the region. Looking closely at the process by which the Tunisian military responded to the 2011 revolution demonstrates the critical role of organizational culture in producing an exceptionally restrained and nonviolent response. To explain why Tunisia's military culture diverged from others across the region, I trace the effects of institutional origins and historical experience on cultural development. This culture of restraint began to emerge from the circumstances of the armed forces' founding at independence, but was insufficiently developed to prevent the army from responding violently to mass protests in 1978 and 1984. Thereafter, the soldiers' negative experiences intervening against mobilized citizens generated a cultural orienta-

\footnotetext{
${ }^{136}$ Aloui, interview.

${ }^{137}$ Bou Nassif, "A Military Besieged,” 80n77.

${ }^{138}$ El Bekri, interview.

${ }^{139}$ Jebnoun, "In the Shadow of Power," 305.
} 
tion toward political neutrality, and declining relations between the military and the political regime further motivated soldiers' pursuit of institutional autonomy. When the revolution began, the army was poised to respond with restraint, allowing the revolution to succeed without mass violence.

The organizational culture perspective differs from existing explanations of military responses, which point to the utilitarian interests of the officer corps to explain decision making during mass protests. In the conventional view, popular uprisings confront soldiers with a binary choice to support either the status quo or the revolution. Weighing the costs and benefits of each option, the officer corps instructs soldiers to defend the regime or to defect in favor of the popular will. While it is undeniable that rational officers, often master tacticians and strategic thinkers, make strategic calculations during political crises, it is my contention that the organizational response to protests is driven primarily by preexisting beliefs and values established prior to the uprising. Just as soldiers train and prepare for future wars, so do they prepare for domestic interventions. Their beliefs, plans, and preparations can play a decisive role in shaping their behavior when faced with the time-pressure and uncertainty of mass protests.

In the security studies literature, the concept of military culture has been central to theoretical understandings of combat performance, cohesion, and conflict outcomes. However, the role of culture has been missing from studies of domestic military intervention. While this article outlines several important sources of organizational culture, future research should investigate how other influences may shape military organizational culture over time. For example, the extensive literature on the effects of foreign military training could benefit from reframing professionalization as a form of cultural change in the recipient military. In light of these findings, scholars should reconsider organizational culture as an integral component of civil-military relations and study its role in shaping military behavior across various political domains. 